\title{
PERBEDAAN SKOR WORK ENGAGEMENT GURU SMP NEGERI DI KECAMATAN DENPASAR UTARA PADA KELOMPOK MASA KERJA 1-4 TAHUN, 5-19 TAHUN, DAN LEBIH DARI 20 TAHUN
}

\author{
Putu Gita Indraswari ${ }^{1}$, I Nyoman Adiputra ${ }^{2}$ \\ Program Studi Pendidikan Dokter Fakultas Kedokteran Universitas Udayana ${ }^{1}$ \\ Bagian Ilmu Faal Fakultas Kedokteran Universitas Udayana ${ }^{2}$
}

\begin{abstract}
ABSTRAK
Work engagement dipengaruhi oleh beban kerja, sumber-sumber kerja, dan sumbersumber pribadi. Namun, terdapat perbedaan hasil penelitian terdahulu mengenai faktor lain yang dapat mempengaruhi work engagement yaitu masa kerja. Penelitian ini bertujuan untuk membuktikan adanya perbedaan skor work engagement guru pada kelompok masa kerja 1-4 tahun, 5-19 tahun, dan lebih dari 20 tahun. Penelitian observasional dengan rancangan cross-sectional dilakukan di SMP Negeri yang terletak di Kecamatan Denpasar Utara, meliputi SMPN 2 Denpasar, SMPN 3 Denpasar, SMPN 4 Denpasar, SMPN 5 Denpasar, SMPN 10 Denpasar, dan SMPN 12 Denpasar. Total subjek yang digunakan dalam penelitian ini adalah sebanyak 147 orang. Skor work engagement dihitung dengan menggunakan Utretch Work Engagement Scale (UWES). Masa kerja guru diklasifikasikan menjadi 1-4 tahun, 5-19 tahun, dan lebih dari 20 tahun. Total skor Work Engagement dibandingkan dengan menggunakan uji Kruskal Wallis dengan tingkat kemaknaan 0,05. Didapatkan hasil bahwa terdapat perbedaan rerata skor work engagement yang signifikan pada kelompok masa kerja 1-4 tahun dengan rerata $79,66 \pm 12,98$ dan kelompok masa kerja lebih dari 20 tahun dengan rerata skor $87,01 \pm 7,99(\mathrm{p}<0.05)$. Hasil yang signifikan juga didapatkan pada kelompok masa kerja 5-19 tahun dengan rerata 80,84 $\pm 8,75$ dan masa kerja lebih dari 20 tahun dengan rerata skor $87,01 \pm 7,99$. Namun, berdasarkan hasil uji korelasi tidak didapatkan hubungan yang bermakna antara masa kerja dan work engagement. Dari hasil penelitian ini, disarankan untuk melakukan upaya-upaya yang dapat meningkatkan work engagement pada kelompok guru dengan masa kerja 1-4 tahun dan 5-19 tahun.
\end{abstract}

Kata kunci : masa kerja, guru, work engagement

\section{DIFFERENCES WORK ENGAGEMENT SCORE ON JUNIOR HIGH SCHOOL TEACHERS IN NORTH DENPASAR WITH 1-4 YEAR, 5-19 YEAR, AND MORE THAN 20 YEAR LENGTH OF SERVICE}

\begin{abstract}
Work engagement is influenced by job demand, job resources, and personal resources. However, there are differences in the results of previous studies on the relationship of length of service with work engagement. This study aims to prove the difference of work engagement score on junior high school teachers in North Denpasar with 1-4 year, 5-19 year, and more than 20 year length of service. It has been implemented an observational study with cross-sectional design, conducted at the Junior High School,
\end{abstract}


located in North Denpasar District, include SMPN 2 Denpasar, SMPN 3 Denpasar, SMPN 4 Denpasar, SMPN 5 Denpasar, SMPN 10 Denpasar, and SMPN 12 Denpasar. Total subjects were used in this study were 147 people. Work engagement scores were calculated using Utretch Work Engagement Scale (UWES). The length of service is classified into 1-4 years, 5-19 years, and more than 20 years. Total Work Engagement Scores were compared using Kruskal-Wallis test with a significance level of 0.05 . Showed that there was an increase in mean scores significantly in group 1-4 years length of service with a mean of $79.66 \pm 12.98$ and group over 20 years with a mean score of $87.01 \pm 7.99(\mathrm{p}<0.05)$. A significant result was also obtained in the group of 5 -19-year length of service with mean score $80.84 \pm 8.75$ and group with over 20 years with a mean score of $87.01 \pm 7.99$. However, based on the correlation test, the association between engagement and length of service is not a significant. It was concluded that there was difference in mean scores significantly in group work period of 1-4 years and group over 20 and also group of 5-19-year length of service with and group with over 20 years. So that should be efforts to improve work engagement in the group of teachers with of 1-4 years and 5-19 years length of service.

Keyword : length of service, teacher, work engagement

\section{PENDAHULUAN}

Pendidikan merupakan salah satu faktor yang berperanan penting dalam seluruh sektor kehidupan. Kualitas pendidikan dapat dipengaruhi oleh berbagai hal. Di Indonesia, guru sebagai garda terdepan dalam proses belajar mengajar merupakan salah satu faktor yang esensial dalam menentukan kualitas peserta didik. Secara tidak langsung dapat dikatakan bahwa kinerja guru yang optimal akan menghasilkan sumber daya manusia yang berkualitas. Oleh karena itu, segala hal yang berkaitan dengan peningkatan kinerja guru, termasuk work engagement pada guru menjadi hal yang patut mendapat perhatian.

Work engagement diartikan sebagai suatu keadaan mental yang positif, memuaskan, dan berhubungan dengan pekerjaan yang dicirikan dengan kekuatan (vigor), dedikasi (dedication), dan pengabdian (absorption). Work engagement seseorang dipengaruhi oleh tuntutan-tuntutan kerja (job demands), sumber-sumber kerja (job resources), 
dan sumber-sumber pribadi (personal resources)(Schaufeli \& Bakker, 2004).

Tuntutan-tuntutan kerja (job demands) mengacu pada aspek fisik, psikologis, sosial, atau organisasi dari pekerjaan yang memerlukan usaha fisik dan atau psikologis secara terus menerus dan dihubungkan dengan pengeluaran secara fisiologis dan atau psikologis tertentu (Schaufeli \& Bakker, 2004). Sumber-sumber kerja (job resources) mempengaruhi work engagement melalui proses motivasional, meliputi dukungan dari rekan kerja dan atasan, umpan balik terhadap kinerja, keterampilan yang beragam, otonomi, dan kesempatan belajar (Handari-Adiputra, 2013).

Sumber sumber pribadi merupakan evaluasi diri yang positif, yang berhubungan dengan kegembiraan dan perasaan individu terhadap kemampuannya dalam mengontrol dan memberi dampak pada lingkungannya dengan sukses. Sumber-sumber pribadi (personal resources) meliputi optimisme, efikasi diri, harga diri, ketahanan dan active coping style (Bakker \& Leiter, 2010).

Hal lain yang diduga berkaitan dengan work engagement adalah masa kerja seseorang. Sementara itu, faktor usia, ras, dan jenjang karir dikatakan tidak memiliki pengaruh yang signifikan terhadap work engagement (Sarkisian, 2011).

Masa kerja menunjukkan berapa lama seseorang bekerja pada masingmasing pekerjaan atau jabatan. Menurut Rahmat (dalam Dewi \& Paramita, 2013) klasifikasi masa kerja untuk guru yang didasarkan pada kemampuannya mengajar, terbagi menjadi masa kerja yang terdiri atas 1-4 tahun dan 5-19 tahun, dan lebih dari 20 tahun.

Berdasarkan penelitian yang dilakukan oleh Wilson (2009), didapatkan hasil bahwa tidak terdapat perbedaan work engagement yang signifikan antara kelompok masa kerja 
tertentu. Sebuah penelitian lain yang dilakukan oleh Wulandari dan Gustomo (2002) menunjukkan hasil yang berbeda, dalam penelitian tersebut didapatkan bahwa variabel masa kerja berpengaruh terhadap tingkat engagement dosen di ITB, melalui peningkatan kompensasi. Pada penelitian tersebut terlihat bahwa seiring peningkatan masa kerja, besaran kompensasi akan semakin meningkat dan berbanding lurus dengan peningkatan work engagement.

Berbeda dengan hasil penelitian yang ditemukan oleh Wulandari \& Gustomo pada tahun 2002, teori yang dikemukakan oleh Gallup (2004) menyatakan bahwa work engagement akan menurun seiring berjalannya waktu. Guru dengan masa kerja kurang dari satu tahun adalah kelompok yang paling terikat (enganged), yakni sebanyak $35,1 \%$. Keterikatan kerja turun menjadi $30,9 \%$ pada guru dengan masa kerja satu sampai tiga tahun, sedangkan guru dengan masa kerja tiga sampai lima tahun memiliki persentase 27,9\%. Keterikatan kerja semakin menurun bagi para guru yang mengajar lebih dari lima tahun.

Perbedaan hasil penelitian tersebut menimbulkan sebuah permasalahan yang harus diselesaikan mengingat work engagement pada guru merupakan salah satu faktor yang nantinya akan berdampak pada kualitas sumber daya manusia yang dihasilkan. Berdasarkan permasalahan tersebut, penulis melakukan sebuah penelitian cross-sectional yang diberi judul "Perbedaan Skor Work Engagement Guru SMP Negeri di Kecamatan Denpasar Utara pada Kelompok Masa Kerja 1-4 Tahun, 5-19 Tahun, dan Lebih dari 20 Tahun.”

\section{BAHAN DAN METODE}

Penelitian ini merupakan penelitian observasional (non eksperimental) dengan pendekatan analitik cross-sectional. Penelitian ini 
dilakukan pada bulan Maret hingga

Nopember 2014 di SMP Negeri yang terletak di Kecamatan Denpasar Utara, meliputi SMPN 2 Denpasar, SMPN 3 Denpasar, SMPN 4 Denpasar, SMPN 5

Denpasar, SMPN 10 Denpasar, dan SMPN 12 Denpasar (Kemendikbud, 2014).

Populasi target penelitian ini adalah guru SMP Negeri. Populasi terjangkau adalah guru SMPN 2 Denpasar, SMPN 3 Denpasar, SMPN 4 Denpasar, SMPN 5 Denpasar, SMPN 10 Denpasar, dan SMPN 12 Denpasar. Dengan kriteria inklusi memiliki kualifikasi pendidikan minimal D4/S1.

Besar sampel ditentukan dengan rumus berikut (Sastroasmoro \& Ismael, 2008) :

$$
\begin{aligned}
& \mathrm{n} 1=\mathrm{n} 2=\mathrm{n} 3=2\left[\frac{(\mathrm{z} \alpha+\mathrm{z} \beta) \mathrm{s}}{(\mathrm{x} 1-\mathrm{x} 2)}\right]^{2} \\
& \mathrm{n} \quad=\text { besar sampel } \\
& \mathrm{z} \alpha \quad=1,96(\alpha=0,05) \\
& \mathrm{z} \beta \quad=1,645(\beta=0,05) \\
& \mathrm{x} 1-\mathrm{x} 2=\text { rerata perubahan yang } \\
& \text { diharapkan }(0,70)
\end{aligned}
$$

$\mathrm{s} \quad=$ simpang baku $(0,67)$

Jadi, total sampel yang diperlukan dalam penelitian ini adalah minimal sebesar 72 orang.

Pemilihan sampel dilakukan dengan teknik consecutive sampling, dimana jumlah sampel yang didapatkan digunakan seluruhnya untuk dapat mewakili setiap kelompok pada populasi.

Dalam penelitian ini seluruh subjek yang memenuhi kriteria inklusi akan diberi penjelasan mengenai tujuan dan manfaat penelitian terlebih dahulu, kemudian diminta menandatangani informed consent apabila bersedia menjadi subjek penelitian.

Instrumen yang digunakan adalah kuesioner UWES (Utrecth Work Engagement Scale) yang terdiri dari 17 buah pertanyaan, 6 buah mencakup aspek vigor (kekuatan), 5 buah pertanyaan mencakup dedication (dedikasi) dan 6 buah pertanyaan mencakup absorption (pengabdian). 
Masing-masing pertanyaan memiliki 6 buah pilihan jawaban dengan skor, meliputi tidak pernah, hampir tidak pernah, jarang, kadang-kadang, sering, sangat sering dan selalu. Skor akhir diperoleh dengan menjumlah skor pada setiap pertanyaan (Handari-Adiputra, 2013).

Data yang telah didapat dianalisis statistik dengan menggunakan program SPSS 20.0.

1) Analisis deskriptif dilakukan untuk menampilkan rerata, simpangan baku, dan rentangan umur subjek penelitian. Selain itu juga dilakukan deskripsi terhadap distribusi jenis kelamin serta pendidikan terakhir subjek penelitian.

2) Uji normalitas data dilakukan dengan menggunakan uji Kolmogorov Smirnov untuk data total skor work engagement pada setiap kelompok masa kerja guru.

3) Uji beda rerata work engagement pada masing-masing kelompok masa kerja dilakukan dengan uji Kruskal-Wallis karena data tidak berdistribusi normal dan varian data tidak homogen.

4) Uji korelasi dilakukan untuk mengidentifikasi hubungan antara masa kerja dengan work engagement pada masing-masing kelompok masa kerja. Uji yang dilakukan adalah Spearman karena data tidak berdistribusi normal.

\section{HASIL PENELITIAN}

Total subjek yang digunakan dalam penelitian ini adalah sebanyak 147 orang, yang terdiri dari 24 orang guru dengan masa kerja 1-4 tahun, 25 guru dengan masa kerja 5-19 tahun, dan 98 orang guru dengan masa kerja lebih dari 20 tahun. Karakteristik subjek penelitian dapat dilihat pada Tabel 1 dan 2. 
Tabel 1. Umur Subjek Penelitian

\begin{tabular}{lccc}
\hline Variabel & Rata- & Simpang & Renta \\
& rata & Baku & ngan \\
& & & \\
\hline Umur & 47,41 & 10,941 & $22-60$ \\
\hline
\end{tabular}

Berdasarkan Tabel 1 didapatkan

bahwa rata-rata umur subjek

$47,41 \pm 10,941$ tahun dengan rentangan 22-60 tahun.

Tabel 2. Jenis Kelamin dan Pendidikan Subjek penelitian

\begin{tabular}{lcccc}
\hline & \multicolumn{2}{l}{ Jenis Kelamin } & \multicolumn{2}{l}{ Pendidikan } \\
\hline & Laki- & Perempuan & D4/S1 & Diatas \\
& laki & & & S1 \\
Frekuensi & 46 & 101 & 126 & 21 \\
Persentase & $31 \%$ & $69 \%$ & $86 \%$ & $14 \%$ \\
\hline
\end{tabular}

Berdasarkan Tabel 2 didapatkan

bahwa $31 \%$ sampel terdiri dari laki-laki

dan $69 \%$ sisanya perempuan. $86 \%$

Sampel memiliki pendidikan terakhir

D4/S1 dan sebanyak 14\% sisanya diatas

S1.

Sebelum melakukan uji beda rerata skor work engagement dilakukan uji normalitas dan uji homogenitas varian yang disajikan pada Tabel 3 dan Tabel 4.

Tabel 3. Uji Normalitas Data

Work Engagement

\begin{tabular}{cccc}
\hline Variabel & $\begin{array}{c}\text { Masa } \\
\text { Kerja }\end{array}$ & $\begin{array}{c}\text { Rata-rata } \pm \\
\text { Simpang } \\
\text { Baku }\end{array}$ & $\mathrm{p}$ \\
\hline $\begin{array}{c}\text { Total skor } \\
\text { work } \\
\text { engagement }\end{array}$ & $\begin{array}{c}1-4 \\
\text { tahun }\end{array}$ & $79,66 \pm 12,98$ & 0,200 \\
& $\begin{array}{c}5-19 \\
\text { tahun } \\
\text { lebih } \\
\text { dari 20 } \\
\text { tahun }\end{array}$ & $80,84 \pm 8,75$ & 0,200 \\
& & \\
\end{tabular}

*data berdistribusi normal $\mathrm{p}>0,05$

Tabel 3 menunjukkan bahwa nilai $\mathrm{p}$ work engagement pada kelompok masa kerja 1-4 tahun dan 5-19 tahun adalah 0,200 , sedangkan nilai $\mathrm{p}$ work engagement untuk kelompok $>20$ tahun adalah 0,010. Karena terdapat satu kelompok yang memiliki nilai $\mathrm{p}<0,05$ maka dapat disimpulkan bahwa data nilai total skor work engagement tidak berdistribusi normal.

Tabel 4. Uji Homogenitas Varian

\begin{tabular}{l} 
Work Engagement \\
\hline Variabel \\
\hline $\begin{array}{c}\text { Total skor } \\
\text { work engagement }\end{array}$ \\
*varian homogen pada $\mathrm{p}>0,05$ \\
Pada Tabel 4, nilai p work \\
engagement adalah 0,010 . Karena nilai
\end{tabular}


$\mathrm{p}<0,05$ maka dapat disimpulkan bahwa ada perbedaan varians data antara kelompok data yang dibandingkan.

Karena data tidak berdistribusi normal dan varians data tidak homogen, maka uji komparabilitas yang dipergunakan adalah uji Kruskal Wallis.

Tabel 5. Uji Komparabilitas Skor Work Engagement pada Masing-Masing

Kelompok Masa Kerja

\begin{tabular}{cc}
\hline Variabel & $\mathrm{p}$ \\
\hline Total skor & 0,002
\end{tabular}

work engagement

*p signifikan pada $\mathrm{p}<0,05$

Dengan uji Kruskal Wallis, diperoleh $\mathrm{p}=0,002$. Oleh karena $\mathrm{p}<0,05$, maka dapat diambil simpulan bahwa paling tidak terdapat perbedaan skor work engagement antara dua kelompok. Selanjutnya, untuk mengetahui kelompok mana yang mempunyai perbedaan, maka dilakukan analisis Post Hoc.
Tabel 6. Analisis Post Hoc

\begin{tabular}{llll} 
Uraian & $\mathrm{p}$ \\
\hline $\begin{array}{l}\text { Kelompok masa kerja } \\
\text { tahun dan 5-19 tahun }\end{array}$ & 0,896 \\
$\begin{array}{l}\text { Kelompok masa kerja } \\
\text { tahun dan lebih dari } 20 \text { tahun }\end{array}$ & 0,011 \\
$\begin{array}{l}\text { Kelompok masa kerja 5-19 } \\
\text { tahun dan lebih dari 20 tahun }\end{array}$ & 0,003 \\
\hline
\end{tabular}

*signifikan pada $\mathrm{p}<0,05$

Tabel 6 menunjukkan bahwa terdapat perbedaan yang signifikan skor work engagement pada kelompok masa kerja 1-4 tahun dengan lebih dari 20 tahun dan kelompok masa kerja 5-19 tahun dengan lebih dari 20 tahun.

Setelah mengetahui adanya perbedaan skor work engagement yang signifikan, selanjutnya akan dilakukan uji korelasi skor work engagement pada masing-masing kelompok untuk mengetahui ada tidaknya hubungan antara masa kerja dengan skor work engagement dalam kelompok tersebut.

Uji korelasi yang dilakukan didahului oleh uji normalitas yang hasilnya disajikan pada Tabel 7. 
Tabel 7. Uji Normalitas Data

Masa Kerja dan Total Skor Work

Engagement

\begin{tabular}{ll}
\hline Variabel & $\mathrm{p}$ \\
\hline Masa Kerja & 0,000 \\
Total Skor Work & 0,010 \\
Engagement & \\
\hline *p signifikan pada $<<0,05$ &
\end{tabular}

Berdasarkan Tabel 7, didapatkan $\mathrm{p}<0,05$ untuk variabel masa kerja dan total skor work engagement hal ini berarti data masa kerja dan total skor work engagement tidak berdistribusi normal. Oleh karena itu, uji korelasi yang dilakukan adalah Spearman.

Tabel 8. Uji Korelasi Masa Kerja dan Work Engagement

\begin{tabular}{lll}
\hline & & $\begin{array}{l}\text { Skor } \\
\text { Engagement }\end{array}$ \\
\hline Masa & $\mathrm{r}$ & 0,116 \\
Kerja & & 0,163 \\
& $\mathrm{p}$ & 147 \\
& $\mathrm{n}$ & 140 \\
\hline
\end{tabular}

*p signifikan pada $\mathrm{p}<0,05$

Berdasarkan Tabel 8 didapatkan hasil bahwa $p>0,05$ yang berarti bahwa tidak terdapat hubungan yang signifikan antara masa kerja dengan work engagement pada kelompok masa kerja 1-4 tahun, 5-19 tahun, maupun lebih dari 20 tahun.

\section{PEMBAHASAN}

Tabel 6 menunjukkan bahwa nilai $\mathrm{p}$ rerata skor work engagement pada kelompok guru dengan masa kerja 1-4 tahun dan 5-19 tahun adalah sebesar 0,896. Hal ini berarti bahwa rerata skor work engagement pada guru dengan masa kerja 1-4 tahun, yaitu 79,66 $\pm 12,98$ dan rerata skor yang diperoleh guru dengan masa kerja 5-19 tahun, yaitu $80,84 \pm 8,75$ tidak berbeda secara bermakna $(p>0,05)$.

Berbeda halnya dengan nilai $p$ rerata skor work engagement pada kelompok guru dengan masa kerja 1-4 tahun dan lebih dari 20 tahun. Berdasarkan Tabel 6 nilai $p$ untuk kelompok guru dengan masa kerja 1-4 tahun dan lebih dari 20 tahun adalah sebesar 0,011 $(\mathrm{p}<0,05)$. Hal ini berarti terdapat perbedaan yang bermakna antara rerata skor work engagement pada guru dengan masa kerja 1-4 tahun, yaitu $79,66 \pm 12,98$ dan guru dengan 
masa kerja lebih dari 20 tahun dengan rerata skor $87,01 \pm 7,99$.

Perbedaan yang bermakna terhadap rerata skor work engagement juga terdapat pada kelompok guru dengan masa kerja 5-19 tahun dan lebih dari 20 tahun. Berdasarkan tabel di atas, nilai $\mathrm{p}$ adalah $0,003(\mathrm{p}<0,05)$. Hal ini berarti terdapat perbedaan yang bermakna antara rerata skor work engagement pada guru dengan masa kerja 5-19 tahun, yaitu $80,84 \pm 8,75$ dan guru dengan masa kerja lebih dari 20 tahun dengan rerata skor $87,01 \pm 7,99$.

Adanya perbedaan rerata skor work engagemet yang signifikan antara kelompok masa kerja 1-4 tahun dengan $>20$ tahun dan 5-19 tahun dengan $>20$ tahun dapat dijelaskan sebagai berikut. Masa kerja yang lama akan cenderung membuat seseorang lebih merasa betah dalam suatu organisasi, hal ini disebabkan diantaranya karena telah beradaptasi dengan lingkungannya yang cukup lama sehingga seseorang akan merasa nyaman dengan pekerjaannya. Hewitt (dalam Mujiasih \& Ratnaningsih, 2012) mengemukakan bahwa engagement juga dipengaruhi oleh beberapa faktor, diantaranya adalah penghargaan (total rewards), kondisi perusahaan (company practices), kualitas kehidupan (quality of life), kesempatan (opportunities), aktivitas pekerjaan yang dihadapi (work) dan orang lain di sekitar pekerjaan (people). Keenam hal tersebut berhubungan dengan work engagement yang tinggi.

$$
\text { Seseorang dengan masa kerja }
$$
yang lama memiliki skor work engagement yang lebih tinggi jika dibandingkan dengan seseorang yang baru bekerja. Hal ini disebabkan oleh adanya kebijakan dari instansi atau perusahaan mengenai jaminan hidup di hari tua serta tingginya imbalan yang dapat diperoleh seseorang, seiring dengan peningkatan masa kerja. Selain itu, masa kerja yang lama akan memberi 
peluang untuk mendapat penghargaan.

Dalam hal ini, penghargaan yang diperoleh guru dapat berupa penghargaan dari instansi tempat bekerja maupun program sertifikasi yang merupakan penghargaan dari pemerintah bagi guru di Indonesia saat ini.

Selain itu, opportunities juga dikatakan dapat mempengaruhi work engagement. Masa kerja seseorang yang lama akan memberi kesempatan atau peluang bagi orang tersebut untuk menduduki jabatan atau posisi yang lebih tinggi (Mujiasih \& Ratnaningsih, 2012).

Teori lain menyebutkan bahwa work engagement dapat dipengaruhi oleh tiga hal, yaitu tuntutan pekerjaan, sumber-sumber kerja, dan sumbersumber pribadi. Dalam hal ini, masa kerja secara tidak langsung akan berpengaruh pada sumber-sumber kerja. Masa kerja seseorang yang lama akan semakin memberi peluang besar bagi orang tersebut untuk menerima tugastugas yang lebih menantang, memberi keleluasaan bekerja, memberi keterampilan yang beragam, otonomi, dan kesempatan belajar yang lebih besar (Schaufeli \& Bakker, 2004).

Setelah mengetahui adanya perbedaan skor work engagement yang signifikan pada kelompok masa kerja 14 tahun dengan kelompok masa kerja lebih dari 20 tahun dan kelompok masa kerja 5-19 tahun dengan kelompok masa kerja lebih dari 20 tahun, selanjutnya akan dilakukan uji korelasi skor work engagement pada masingmasing kelompok untuk mengetahui ada tidaknya hubungan antara masa kerja dengan skor work engagement dalam kelompok tersebut.

Berdasarkan Tabel 8 didapatkan hasil bahwa $p>0,05$ yang berarti bahwa tidak terdapat hubungan yang signifikan antara masa kerja dengan work engagement pada kelompok masa kerja 1-4 tahun, 5-19 tahun, maupun lebih 
dari 20 tahun. Hal ini bisa dijelaskan sebagai berikut, dalam penelitian ini terdapat sampel dengan masa kerja lebih rendah yang memiliki skor work engagement yang sama atau lebih tinggi dari skor work engagement yang dimiliki oleh guru dengan masa kerja yang lebih tinggi. Hal ini dapat terjadi apabila guru dengan masa kerja yang lebih rendah memiliki sumber-sumber kerja yang baik, seperti mendapat dukungan dari rekan kerja dan adanya umpan balik dari atasan. Selain itu, sumber-sumber pribadi yang merupakan suatu keadaan psikologis berupa optimisme juga turut berpengaruh.

Begitupula sebaliknya, guru dengan masa kerja yang lebih tinggi dapat memiliki skor work engagement yang rendah apabila tidak memiliki sumber-sumber kerja dan sumbersumber pribadi yang baik.

Jika dikaitkan dengan uji komparabilitas yang telah dilakukan, maka dapat disimpulkan bahwa terdapat perbedaan skor work engagement yang signifikan pada kelompok masa kerja 14 tahun dengan kelompok masa kerja lebih dari 20 tahun dan kelompok masa kerja 5-19 tahun dengan kelompok masa kerja lebih dari 20 tahun. Namun, berdasarkan hasil uji korelasi tidak didapatkan hubungan yang bermakna pada masing-masing kelompok kerja.

Dengan kata lain, dapat disimpulkan bahwa guru dengan masa kerja lebih dari 20 tahun lebih enganged dengan pekerjaannya jika dibandingkan dengan guru yang memiliki masa kerja 1-4 tahun dan 5-19 tahun. Namun tidak dapat dikatakan bahwa peningkatan masa kerja akan meningkatkan skor work engagement seseorang.

Dalam penelitian ini, peneliti masih belum memperhitungkan penghargaan sebagai salah satu variabel yang dapat mempengaruhi work engagement. Penghargaan yang dimaksud adalah adanya sertifikasi.

\section{SIMPULAN}


1. Terdapat perbedaan skor work engagement antara kelompok guru masa kerja kerja 1-4 tahun dengan lebih dari 20 tahun dan 5-19 tahun dengan lebih dari 20 tahun.

2. Tidak terdapat hubungan yang signifikan antara masa kerja dengan work engagement pada kelompok masa kerja 1-4 tahun.

3. Tidak terdapat hubungan yang signifikan antara masa kerja dengan work engagement pada kelompok masa kerja 5-19 tahun.

4. Tidak terdapat hubungan yang signifikan antara masa kerja dengan work engagement pada kelompok masa kerja lebih dari 20 tahun.

\section{DAFTAR PUSTAKA}

Bakker, A. B. \& Leiter, M. P. 2010 Work engagement : A Handbook of Essential Theory and Research. New York: Psychology Press.

Dewi, S. L. \& Paramita, P. P. 2013. Tingkat Burnout Ditinjau dari Karakteristik Demografis (Usia,
Jenis Kelamin dan Masa Kerja) Guru

SDN Inklusi di Surabaya. Jurnal Psikologi Pendidikan dan Perkembangan 1. Vol. 2 : 1-9.

Gallup. 2014. In U.S., Newer Teachers Most Likely to Be Engaged at Work, Engagement falls about four percentage points after one year at work. [serial online] [diakses 9 Januari 2014] Diunduh dari: URL: $<$ http://www.gallup.com/poll/1 63745/newer-teachers-likelyengaged-work.aspx $>$

Handari-Adiputra, L. M. I. S. 2013. Ergo-Psikofisiologi Menurunkan Respon Fisiologis, Meningkatkan Kesigapan, Kemampuan Kerja, dan Work Engagement Karyawan Bagian Akuntansi Hotel Bali Hyatt Di Denpasar. [disertasi]. Denpasar: Universitas Udayana.

Kementrian Pendidikan dan Kebudayaan. 2014. Daftar Satuan Pendidikan (Sekolah) per Kecamatan Denpasar Utara. [serial online] 
[diakses 8 Februari 2014]. Diunduh

dari

URL

$:<\underline{\text { http://referensi.data.kemdikbud.go. }}$ $\underline{\mathrm{id} / \mathrm{index} 11 \text { smp.php?kode }=226004 \&}$ $\underline{\text { level }=3>}$

Mujiasih, E. \& Ratnaningsih, I. Z. 2012. Meningkatkan Work Engagement Melalui Gaya Kepemimpinan Transformasional dan Budaya Organisasi. Semarang: Universitas Diponegoro.

Sarkisian, N. 2011. Effects of Country \& Age on Work Engagement, Job Satisfaction \& Organizational Commitment Among Employees in the United States. Chestnut Hill, MA: Sloan Center on Aging \& Work at Boston College.

Sastroasmoro, S. \& Ismael, S. 2008. Dasar-dasar Metodologi Penelitian Klinis. Jakarta: CV Sagung Seto.

Schaufeli, W. B. \& Bakker, A. B. 2004. Job Demands, Job Resources, and Their Relationship with Burnout and
Engagement : A Multi-Sample Study. J. Organiz. Vol. 6: 293-315.

Wilson, K. 2009. A Survey of Employee Engagement. [disertasi]. Columbia: University of Missouri.

Wulandari, P. \& Gustomo, A. 2002. Analisis Pengaruh Total Returns terhadap Tingkat Engagement Dosen Institut Teknologi Bandung. Bandung: Institut Teknologi Bandung. 